\title{
PENINGKATAN HASIL BELAJAR MATERI PERSAMAAN DAN PERTIDAKSAMAAN LINEAR SATU VARIABEL SISWA DENGAN COOPERATIVE LEARNING TIPE STAD
}

\author{
Totok Riwanto \\ Sekolah Menengah Pertama Negeri 1 Kampak Trenggalek, jalan anggrek no No.1, Kedungrowo, \\ Bendoagung, Kampak, Kabupaten Trenggalek, Jawa Timur 66373, totokriwanto@gmail.com
}

Diterima 3 Januari 2020, disetujui 16 April 2020, diterbitkan 30 April 2020

Pengutipan: Riwanto, T. (2020). Peningkatan Hasil Belajar Materi Persamaan dan Pertidaksamaan Linear Satu Variabel Siswa Dengan Cooperative Learning Tipe STAD. Gema Wiralodra, Vol 11, No 1, Hal 82-89, April 2020

\begin{abstract}
ABSTRAK
Tujuan penelitian ini untuk meningkatkan hasil belajar matematika materi persamaan dan pertidaksamaan linear satu variabel (PLSV dan PtLSV) dengan metode pembelajaran kooperatf tipe STAD. Partisipan yang terlibat dalam penelitian ini yakni siswa kelas VII F di salah satu SMP Negeri yang ada di Trenggalek tahun pelajaran 2019/2020 dengan jumlah siswa 29 terdiri dari 19 siswa laki-laki dan10 siswa perempuan. Teknik pengumpulan data dengan cara test tulis. Desain Penelitian yang digunakan yakni penelitian tindakan kelas yang dilaksanakan dalam 2 siklus. setiap siklus terdiri dari perencanaan, pelaksanaan tindakan, observasi, evaluasi, dan refleksi. Hasil penelitian menunjukkan adanya peningkatan hasil belajar siswa pada materi persamaan dan pertidaksamaan linier satu variabel (PLSV dan PtLSV) dari nilai PTS 1 ke Siklus I dan dari siklus I ke siklus II. Hal ini ditunjukan dengan perolehan rata-rata hasil PTS 1 yaitu 52,3 meningkat dalam siklus I menjadi 66,7 pada siklus I dan 84,4 pada siklus II. Demikian pula untuk ketuntasan belajar juga mengalami peningkatan,hal ini ditunjukan dari persentase ketuntasan belajar pada hasil PTS 1 yaitu 21\%, siklus I yaitu 58\% dan pada siklus II yaitu 93\%. Dapat disimpulkan bahwa penerapan pembelajaran kooperatif learning tipe STAD dapat meningkatkan hasil belajar siswa kelas VII F pada materi persamaan dan pertidaksamaan linier satu variabel ( PLSV dan PtLSV) tahun pelajaran 2019/2020.

Kata kunci: PLSV dan PtLSV, pembelajaran kooperatif learning tipe STAD, Hasil Belajar
\end{abstract}

\begin{abstract}
The purpose of this study was to improve mathematics learning outcomes of material equations and one variable linear inequality (PLSV and PtLSV) with STAD type cooperative learning methods. Participants involved in this study were students of class VII $\mathrm{F}$ in one of the state junior high schools in Trenggalek in the academic year 2019/2020 with 29 students consisting of 19 male students and 10 female students. Data collection techniques by writing test. The research design used is classroom action research conducted in 2 cycles. each cycle consists of planning, implementing actions, observing, evaluating, and reflecting. The results showed an increase in student learning outcomes in the material equation and linear inequality of one variable (PLSV and PtLSV) from the value of PTS 1 to Cycle I and from cycle I to cycle II. This is indicated by the average acquisition of PTS 1 ie 52.3 increased in cycle I to 66.7 in cycle I and 84.4 in cycle II. Likewise for mastery learning also increased, this is shown from the percentage of mastery learning in PTS 1 results that is $21 \%$, cycle I is $58 \%$ and cycle II is 93\%. It can be concluded that the application of STAD type cooperative learning can improve the learning outcomes of Class VII F students on the material of equality and linear inequality of one variable (PLSV and PtLSV) in the academic year 2019/2020.
\end{abstract}


Keywords: PLSV and PtLSV, STAD type cooperative learning, Learning Outcomes

\section{PENDAHULUAN}

Proses pedagogik merupakan salah satu faktor yang menentukan keberhasilan siswa dalam memahami materi. Oleh karena itu, berdasarkan Permendiknas No. 16 Tahun 2007, guru harus memiliki empat kompentensi salah satunya guru harus mampu memiliki kemampuan pedagogik. Selain itu seorang guru harus mampu memilih dan menemukan model pembelajaran yang tepat untuk materi tertentu (Wijanarko, 2017). Menurut Permendikbud Nomor 81 A Tahun 2013 lampiran IV, proses pembelajaran terdiri atas lima pengalaman belajar pokok yaitu: mengamati; menanya; mengumpulkan informasi/eksperimen; mengasosiasikan/ mengolah informasi; dan. mengkomunikasikan. Salah satu alternatif agar pembelajaran menarik dan tidak monoton khususnya pada mata pelajaran matematika yakni menggunakan model pembelajaran kooperatif.

Berdasarkan pengamataan terjadi penurunan nilai Ujian Nasional yang sangat drastis dari tahun pelajaran 2017/2018 ke tahun pelajaran 2018/2019, hal ini disebabkan pada tahun pelajaran 2018/2019 jumlah soal HOTS ( Higher Order Thinking Skills ) ditingkatkan menjadi 30 - 40\% dari tahun sebelumnya. Persamaan dan pertidaksamaan satu variable (PLSV dan PtLSV) merupakan materi yang cukup sederhana yang termasuk dalam SKL tetapi menurut pengamatan merupakan celah terjadinya kesalahan saat Ujian nasional karena sering muncul sebagai soal level 2 atau bahkan level 3 (HOTS). Berdasarkan pengamatan pada hasil PTS 1 pada kelas VII F, terlihat bahwa sebagian besar siswa kelas VII F minat belajar matematikanya masih rendah, dari keseluruhan siswa 29 dengan jumlah siswa laki-laki 19 dan perempuan 10, hanya ada 6 siswa yang mencapai KKM, sedangkan dilihat dari rata-rata seluruh kelas VII, dapat dilihat bahwa nilai rata-rata VII F paling rendah.

Hal ini menjadi penyebab tertariknya pengambilan subyek penelitian di kelas VII F karena peneliti ingin lebih fokus kepada hasil belajar matematika di kelas yang hasilnya lebih rendah dengan kelas lainnya. Hasil belajar merupakan kemampuan yang dimiliki oleh siswa yang dapat diketahui dari perubahan tingkat pengetahuan siswa (Ismunandar, D \& Nurafifah, L, 2018). Berdasarkan 
pengamatan peneliti di kelas VII F ini masih banyak siswa kurang memahami konsep, aturan, struktur matematika serta kurang aktif berpartisipasi dalam aktivitas pembelajaran di kelas. Sebenarnya di kelas VII F dari sisi perlakuan, fasilitas, kelengkapan pada proses pembelajaran sama dengan kelas lainnya namun hasilnya belum memenuhi harapan yaitu nilai KKM 60. Mungkin ada penyebab lainnya misalnya, masih kurang siapnya siswa dalam mengikuti pelajaran yang ditunjukkan dengan adanya siswa yang tidak membawa alat tulis atau buku matematika, kurang aktif bertanya setelah guru menerangkan, guru kurang Paikem dan guru belum menggunakan variasi model pembelajaran. Pembelajaran secara klasikal mungkin juga menyebabkan keaktifan siswa kurang terlihat, juga saat siswa mengerjakan latihan cenderung hanya bercerita atau bercanda dengan siswa yang lain. Karena itulah peneliti mencoba mengadakan perbaikan perlakuan dengan memperhatikan hal-hal tersebut di atas dengan pembelajaran Paikem (Pembelajaran Aktif, Inovatif, Kreatif, Edukatif dan Menyenangkan) yaitu metode cooperative learning tipe STAD.

Metode pembelajaran cooperative learning tipe STAD merupakan salah satu metode pembelajaran yang variatif dan menyenangkan (Winarto, 2018). Metode cooperative learning tipe STAD merupakan suatu rangkaian kegiatan belajar yang melibatkan secara maksimal seluruh kemampuan siswa untuk mencari dan menyelidiki secara sistematis, kritis, logis, analitis sehingga mereka dapat menyelesaikan sendiri secara mandiri (Budiyanto, 2016). Dalam hal ini peranan guru sangat menentukan, karena guru selain sebagai pemberi informasi guru juga sebagai motivator, fasilitator dan pengarah (Sundari, 2017). Pembelajaran metode cooperative learning tipe STAD ini terbentuk dari siswa itu sendiri dengan bantuan guru. Dalam penelitian ini, peneliti yang bertindak sebagai guru, memberikan kesempatan kepada siswa untuk menemukan sendiri dengan anggota kelompoknya dalam menyelesaikan soal-soal matematika dengan bimbingan dari peneliti.

\section{METODE PENELITIAN}

Jenis penelitian yang digunakan yakni penelitian tindakan kelas. Partisipan yang terlibat dalam penelitian yakni siswa kelas VII F SMP Negeri di 1 Kampak dengan jumlah siswa 29 anak terdiri dari 19 siswa laki-laki dan 10 siswa 
perempuan. Alasan memilih kelas VII F sebagai subyek penelitian, karena kondisi siswa kelas VII F dibandingkan dengan kelas yang lain prestasi belajar matematikanya paling rendah. Untuk memperoleh data yang dapat dipertanggungjawabkan, maka data yang digunakan dalam penelitian ini diperoleh dengan cara menggunakan tes dan observasi. Pengumpulan data pada penelitian ini menggunakan instrumen berupa tes digunakan untuk mengetahui hasil belajar matematika secara individu pada setiap akhir siklus. Teknik analisa data merupakan unsur yang sangat penting dalam setiap kali melakukan penelitian. Semua data yang telah terkumpul tidak akan berarti kalau tidak diadakan penganalisaan. Hasil dari penganalisaan akan memberikan gambaran, arah serta tujuan dan maksud penelitian. Penelitian ini menggunakan analisa statistik sederhana, yaitu dengan analisa deskriptif. Analisa deskriptif adalah model analisa dengan cara membandingkan rata-rata prosentasenya, kemudian kenaikan ratarata pada setiap siklus. Disini yang dianalisa yaitu tentang hasil ulangan pada tiap siklus. Dari hasil ulangan tersebut, dapat ditafsirkan tentang ketuntasan belajar klasikal.

Pada penelitian ini, peneliti menentukan patokan keberhasilan penelitian jika peningkatan prestasi belajar matematika yang memenuhi ketuntasan belajar secara klasikal yaitu 75\% dari jumlah siswa keseluruhan di kelas VII F. Siswa dikatakan tuntas jika nilai hasil ulangan mencapai minimal 60 (KKM mata pelajaran matematika SMP Negeri 1 Kampak tahun pelajaran 2019/2020)

Penelitian tindakan kelas ini rencananya akan dilaksanakan dalam 2 siklus, yang tiap siklusnya dilaksanakan 2 kali pertemuan dengan alokasi waktu 2x40 menit dan 3x40 menit. Setiap siklus terdiri dari kegiatan yang meliputi perencanaan, pelaksanaan tindakan, observasi, evaluasi, dan refleksi. Pada akhir siklus diadakan tes/evaluasi berupa penilaian harian untuk mengetahui besarnya peningkatan hasil belajar matematika .

\section{HASIL PENELITIAN DAN PEMBAHASAN}




\section{Prasiklus}

Pada pembelajaran awal sebelum perbaikan, hasil belajar siswa masih rendah. Hal ini dapat dilihat dari hasil penilaian tengah semester 1 yaitu 6 atau21\% siswa yang tuntas dari 29 siswa dengan nilai rata-rata kelas hanya 52,3.

\section{Siklus I}

Kegiatan pembelajaran pada siklus I sudah menggunakan metode pembelajaran cooperative learning tipe STAD. Setelah siklus I berakhir untuk mengetahui hasil belajar siswa maka diberikan test/ulangan harian dan hasilnya dianalisis untuk mengetahui tingkat ketuntasan belajar siswa. Berdasarkan analisis nilai hasil tes pada siklus I, terjadi peningkatan hasil belajar seperti terlihat pada tabel berikut:

Tabel Hasil Belajar Siswa Pada PTS 1 dan Siklus I

\begin{tabular}{llll}
\hline No. & Uraian & Studi Awal & Siklus I \\
\hline 1. & Rata-rata & 52,3 & 66,7 \\
\hline 2. & Siswa yang tuntas & 6 & 17 \\
\hline 3. & Siswa yang tidak tuntas & 23 & 12 \\
\hline 4. & Persentase siswa yang tuntas & $21 \%$ & $58 \%$ \\
\hline 5. & $\begin{array}{l}\text { Persentase siswa yang tidak } \\
\text { tuntas }\end{array}$ & $79 \%$ & $42 \%$ \\
\hline
\end{tabular}

Tabel di atas menunjukan adanya peningkatan hasil belajar siswa. Jumlah siswa yang tuntas belajar pada studi awal 6 siswa atau 21\% dan siswa yang belum tuntas 23 siswa atau $89 \%$ dengan nilai rata-rata 52,3. Pada siklus I hasil belajar meningkat dengan nilai rata-rata 66,7 dan siswa yang tuntas belajar sebanyak 17 siswa atau 58\%. Pada siklus ini sudah mengalami peningkatan, tetapi belum mencapai kriteria yang diinginkan yaitu persentase siswa yang tuntas $75 \%$ dari jumlah siswa keseluruhan di kelas VII F.

Berdasarkan hasil refleksi yang menyimpulkan bahwa motivasi siswa dalam mengikuti proses pembelajaran masih rendah, keseriusan dalam mengerjakan LKS dalam kelompok belum maksimal dan siswa terlihat jenuh, maka peneliti melakukan revisi pada RPP dan skenario tindakan yaitu memberikan motivasi dengan menginformasikan bagi kelompok peraih rata-rata nilai tertinggi akan mendapat hadiah, pemberian ice breaking dan pemanfaatan teknologi dalam pembelajaran khususnya LCD. Selama kegiatan kelompok 
berlangsung, guru mengawasi kerja siswa dalam kelompoknya ketika melengkapi isian-isian soal latihan dengan cara diskusi dengan anggota kelompoknya. Kegiatan dilanjutkan presentasi hasil diskusi kelompok dengan melibatkan siswa dalam pemanfaatan TIK. Kegiatan juga diselingi ice breaking supaya siswa tidak jenuh dengan kegiatan pembelajaran yang diikuti.

Peneliti bersama siswa menyimpulkan materi yang telah dipelajari. Siswa mengerjakan tes yang telah disediakan peneliti dan hasilnya sebagai data pada siklus.

\section{Siklus II}

Berdasarkan analisis hasil tes pada siklus II terjadi peningkatan hasil belajar siswa, seperti terlihat pada tabel di bawah ini :

Tabel Hasil Belajar Siswa pada Studi Awal, Siklus I dan Siklus II

\begin{tabular}{llll}
\hline Uraian & $\begin{array}{l}\text { Studi } \\
\text { Awal }\end{array}$ & Siklus I & Siklus II \\
\hline Rata-rata & 52,3 & 66,7 & 84,4 \\
\hline Siswa yang tuntas & 6 & 17 & 27 \\
\hline Siswa yang tidak tuntas & 23 & 12 & 2 \\
\hline Persentase siswa yang tuntas & $21 \%$ & $58 \%$ & $93 \%$ \\
\hline Persentase siswa yang tidak tuntas & $79 \%$ & $42 \%$ & $7 \%$ \\
\hline
\end{tabular}

Berdasarkan tabel di atas diketahui adanya peningkatan hasil belajar siswa cukup menggembirakan pada siklus II yaitu 27 siswa tuntas atau $93 \%$. Peningkatan hasil belajar pada siklus II sudah mencapai kriteria yang diharapkan yaitu $75 \%$ dari jumlah siswa telah meningkat. Rata-ratanya juga sudah meningkat yaitu 84,4 .

Ketuntasan hasil belajar pada siklus II sudah mencapai 93\% yaitu sebanyak 27 siswa dari 29 siswa. Berdasarkan kriteria ketuntasan hasil belajar siswa telah tercapai maka penelitian tidak dilanjutkan ke siklus berikutnya. Pada siklus II, peneliti melakukan revisi pada RPP dan skenario tindakan. Pada siklus II peneliti memberikan perhatian khusus pada siswa yang masih pasif berdasarkan pengamatan pada siklus sebelumnya. Ketuntasan belajar mengalami peningkatan $35 \%$ dari siklus I ke siklus II. Secara keseluruhan hasil belajar siswa sudah mencapai kriteria indikator keberhasilan. 


\section{Pembahasan}

Berdasarkan hasil penelitian menunjukkan bahwa penggunaan pembelajaran kooperatif tipe STAD dapat meningkatkan hasil belajar matematika. Hal ini selaras dengan penelitinnya (1) Megawaty, S. (2017) berdasarkan pembahasan serta analisis yang telah dilakukan dapat disimpulkan pembelajaran dengan model belajar aktif model pembelajaran tipe STAD dapat meningkatkan prestasi belajar siswa dalam setiap siklus, yaitu pra siklus 30\%, siklus I 73,33\% dan siklus II 100\% dengan KKM 70. (2) Putri, M. T., Anggraini, R. D., \& Saragih, S. (2014) dari hasil penelitian ini adalah penerapan model pembelajaran kooperatif Tipe Student Teams-Achievement Divisions (STAD) dapat meningkatkan komunikasi matematika siswa kelas VIIA3 MTs Darul Hikmah Pekanbaru pada semester ganjil tahun pelajaran 2014/2015. (3) Tiska, T., Mallo, B., \& Hamid, A (2017) Hasil penelitian menunjukkan bahwa penerapan model kooperatif tipe $S T A D$ dapat meningkatkan hasil belajar siswa pada materi persamaan linear satu variabel mengikuti tahap-tahap, yaitu: 1) menyampaikan tujuan dan memotivasi siswa, 2) menyajikan/menyampaikan informasi, 3) mengorganisasikan siswa dalam kelompok-kelompok belajar, 4) membimbing kelompok dalam bekerja dan belajar, 5) evaluasi, 6) memberikan penghargaan.

\section{KESIMPULAN}

Berdasarkan hasil penelitian mengenai penggunaan Model Pembelajaran STAD pada mata pelajaran matematika di kelas VIIF SMP Negeri Kampak tahun Pelajaran 2019/ 2020 maka dapat ditarik kesimpulan sebagai berikut: Metode pembelajaran kooperatif tipe STAD dapat meningkatkan hasil belajar siswa kelas VIIF SMP Negeri 1 Kampak. Peningkatan hasil belajar ditunjukkan dengan hasil penilaian harian pada masing-masing tahapan. Tingkat ketuntasan pada PTS 1 yaitu $21 \%$, siklus $\mathrm{I}=58 \%$, dan siklus $\mathrm{II}=93 \%$. Rata-rata hasil penilaian harian juga mengalami peningkatan yaitu 52,3 (nilai awal PTS 1), siklus 1 yaitu 66,7 dan siklus 2 yaitu 84,4 .

\section{DAFTAR PUSTAKA}

Budiyanto, M. A. K. (2016). SINTAKS 45 Model Pembelajaran dalam Student Centered Learning (SCL). Malang: UMM Press 
Ismunandar, D \& Nurafifah, L. (2018). Efektifitas Penggunaan Buku Ajar Berbantuan Geogebra untuk Mencapai Ketuntasan Hasil Belajar Matematis. Dialektika, 5(2), 70-85.

Putri, M. T., Anggraini, R. D., \& Saragih, S. (2014). Penerapan Model Pembelajaran Kooperatif Tipe Student Teams-achievement Divisions (STAD) untuk Meningkatkan Komunikasi Matematika Siswa Kelas Vii MTs Darul Hikmah Pekanbaru. Jurnal Online Mahasiswa Fakultas Keguruan dan Ilmu Pendidikan Universitas Riau, 3(2), 1-10.

Sundari, F. (2017). Peran Guru sebagai Pembelajar dalam Memotivasi Peserta Didik Usia SD.

Sri Megawaty, S. (2017). Meningkatkan Prestasi Belajar Siswa Tentang Persamaan Linier dan Pertidaksamaan Linier Satu Variabel Bidang Studi Matematika Menggunakan Model Pembelajaran Stad pada Siswa Kelas VII SMPN 2 Tambusai. Jurnal Ilmiah Edu Research Vol, 6(1), 7.

Tiska, T., Mallo, B., \& Hamid, A. (2017). Penerapan Model Pembelajaran Kooperatif Tipe Student Team Achievement Division Untuk Meningkatkan Hasil Belajar Siswa Kelas Vii Smp 1 Sindue Tombusabora Pada Materi Persamaan Linear Satu Variabel. Jurnal Elektronik Pendidikan Matematika Tadulako, 4(4).

Wijanarko, Y. (2017). Model Pembelajaran Make A Match Untuk Pembelajaran IPA Yang Menyenangkan. TAMAN CENDEKIA: Jurnal Pendidikan KeSD-an, 1(1), 52-59.

Winarto, B. (2018). Peningkatan Ketuntasan Hasil Belajar Matematika Menggunakan Model Cooperative Learning Tipe STAD melalui Pemanfaatan Alat Peraga. Jurnal Pendidikan Matematika (JUDIKA EDUCATION), 1(1), 12-20. 